\title{
Climate change evidence in tree growth and stand productivity at the upper treeline ecotone in the Polar Ural Mountains
}

Nadezhda M. Devi, Vladimir V. Kukarskih º, Arina A. Galimova, Valeriy S. Mazepa and Andrey A. Grigoriev

\begin{abstract}
Background: Recent warming is affecting species composition and species areal distribution of many regions. However, although most treeline studies have estimated the rates of forest expansion into tundra, still little is known about the long-term dynamic of stand productivity at the forest-tundra intersection. Here, we make use of tree-ring data from 350 larch (Larix sibirica Ledeb.) and spruce (Picea obovata Ledeb.) sampled along the singular altitudinal treeline ecotone at the Polar Urals to assess the dynamic of stand establishment and productivity, and link the results with meteorological observations to identify the main environmental drivers.

Results: The analysis of stand instalment indicated that more than 90\% of the living trees appeared after 1900. During this period, the stand became denser and moved $50 \mathrm{~m}$ upward, while in recent decades the trees of both species grew faster. The maximum afforestation occurred in the last decades of the twentieth century, and the large number of encountered saplings indicates that the forest is still expanding. The upward shift coincided with a slight increase of May-August and nearly doubling of September-April precipitation while the increase in growth matched with an early growth season warming (June $+0.27^{\circ} \mathrm{C}$ per decade since 1901). This increase in radial growth combined with the stand densification led to a 6-90 times increase of biomass since 1950.

Conclusion: Tree-ring based twentieth century reconstruction at the treeline ecotone shows an ongoing forest densification and expansion accompanied by an increased growth. These changes are driven by climate change mechanism, whereby the leading factors are the significant increase in May-June temperatures and precipitation during the dormant period. Exploring of phytomass accumulation mechanisms within treeline ecotone is valuable for improving our understanding of carbon dynamics and the overall climate balance in current treeline ecosystems and for predicting how these will be altered by global change.
\end{abstract}

Keywords: Polar Urals, Treeline, Productivity, Climate change, Radial growth, Recruitment, Larch, Spruce

\section{Background}

Global warming is most pronounced at high latitudes where temperatures over the last 30 years have risen by $0.6^{\circ} \mathrm{C}$ per decade, which is twice as fast as the global average (Bekryaev et al. 2010; Core Writing Team RKP and LAM 2014). Since it is largely considered that high altitude and latitude treelines are controlled by summer temperatures (Holtmeier and Broll 2007; Gehrig-Fasel

\footnotetext{
* Correspondence: voloduke@mail.ru

Institute of Plant and Animal Ecology, Ural Branch, Russian Academy of Sciences, 8 Marta, 202/3, Ekaterinburg 620144, Russia
}

et al. 2008; MacDonald et al. 2008) and growing season parameters (Körner and Paulsen 2004; Körner 2008), the ongoing warming trend is expected to cause important vegetation shifts and lead to significant changes in species composition and biomass production (Walther et al. 2002; Epstein et al. 2004; Gonzalez et al. 2010; Paulsen and Körner 2014; Speed et al. 2015). Despite the fact that treeline advances in Polar regions are mostly limited by temperature, other factors (e.g. slope aspect, geomorphic processes, snow cover, albedo, soil temperatures, and carbon and nutrient cycling) can determine 
the rates of this changes (Holtmeier 2003; Lloyd 2005; Macias-Fauria and Johnson 2013; Loranty et al. 2014).

Many studies focusing on ongoing dynamics of woody vegetation at the limit of their distribution (e.g. Harsch et al. 2009; Holtmeier 2009; Körner 2012) have documented that treelines are experiencing an extension of seedling establishment, densification of forest structures and a stimulation of radial growth and biomass (e.g. Kearney 1982; Wardle and Coleman 1992; Nicolussi et al. 1995; Kullman and Engelmark 1997; Canadell et al. 2007) that are consistent with observed rates of recent (Suarez et al. 1999; Gamache and Payette 2005; Shiyatov et al. 2007) and past (Foley et al. 1994; Lloyd and Graumlich 1997; Grace et al. 2002; Körner and Paulsen 2004; Hoch and Körner 2009) temperature changes.

However, other studies suggest that winter temperature and precipitation also affect on the survival of treeline trees as they play a role on soil hydrological and thermal regimes (Harsch et al. 2009; Hagedorn et al. 2014). Indeed, increased winter precipitation may provide additional water supply for woody vegetation (especially seedlings and saplings) during the vegetation period (Grigorieva and Moiseev 2018), while snow cover plays a key role in protecting them and young trees from frost and wind damage (Holtmeier 2009; Devi et al. 2008; Kharuk et al. 2010, 2017). In contrast to low latitudes and altitudes, where forest distribution is mainly limited by lack of moisture (Woodward et al. 2004), forests from cold regions can grow with less than $400 \mathrm{~mm}$ of yearly precipitation, which is usually sufficient to cover trees' transpiration needs (Pan et al. 2013).

Most treeline studies have focused on understanding drivers and limitations of the treeline shift, whereas knowledge of tree biomass and productivity and the environmental factors influencing biomass production is severely limited. Extensive studies have assessed biomass changes using remote sensing methods (e.g. Pan et al. 2013; Zolkos et al. 2013) and have mainly focused on mountain systems from temperate climatic zones that are exposed to anthropogenic disturbances. However, satellites or aerial scanning data can only assess biomass dynamics of the last decades and the current changes in anthropogenic pressure might have slightly biased the obtained results. Currently, only some studies have investigated centennial trends in aboveground biomass as a result of changing environmental conditions based on direct field observations (Clark et al. 2001; Babst et al. 2014; Grafius and Malanson 2015; Moiseev et al. 2016; Liu et al. 2016; Xu et al. 2019) and analyzing tree-ring data (Graumlich et al. 1989; Dye et al. 2016), making it difficult to quantify current trends in the carbon sequestration and productivity of terrestrial ecosystems.
The Polar Ural Mountains are particularly suitable for investigating climate-induced processes as they have not been influenced by any significant disturbances. Indeed, the mountainous part of the Polar Urals has been excluded from reindeer grazing, logging and other management activities, and its vegetation has not been exposed to forest fires for the last 500 years, as evidenced by the absence of charred tree and coal residues in the upper soil layers (Mazepa 2005).

The aim of this investigation was to identify the main drivers of the treeline dynamic processes at the Polar Urals. Our specific objectives were to assess, along an altitudinal gradient and over the last century, the development of (1) stand formation; (2) radial growth; (3) and biomass accumulation; (4) to eventually identify the climatic drivers to such developments.

\section{Methods \\ Study area}

The investigated treeline ecotone is located about $30 \mathrm{~km}$ north of the Arctic Circle on the western slope of the mountain Slantsevaya $\left(66^{\circ} 54^{\prime} \mathrm{N}, 65^{\circ} 44^{\prime}\right.$ E), close to Sob River basin, an eastern slope of the Polar Ural Mountains (Fig. 1, Fig. 3). The area belongs to the Yamalo-Nenets Autonomous Okrug (YANAO) of Russia and is part of the continental subarctic zone.

Monthly meteorological records from 1892 to 2015 of the nearest weather station of Salekhard $\left(66^{\circ} 32^{\prime}\right.$ $\mathrm{N}, 66^{\circ} 32^{\prime} \mathrm{E} ; 35 \mathrm{~m}$ a.s.l.; located $50 \mathrm{~km}$ southeast from the research area) indicate a negative average annual temperature $\left(-6.4^{\circ} \mathrm{C}\right)$ and mean annual precipitation of $415 \mathrm{~mm}$, with $45 \%$ of which fall as snow (Fig. 2). The region is characterized by a complex wind regime dominated by westerly winds, with average speed of $8.5-8.8 \mathrm{~m} \cdot \mathrm{s}^{-1}$ in winter and $6.5-7.0 \mathrm{~m} \cdot \mathrm{s}^{-1}$ in summer. The current treeline occurs between 260 to $310 \mathrm{~m}$ a.s.l. and is dominated by Siberian larch (Larix sibirica Ledeb.) in association with Siberian spruce (Picea obovata Ledeb.) and mountain alder (Alnus alnobetula ssp. fruticosa (Rupr.) Raus.). The shrub layer is dominated by Betula nana L. with a mixture of different willows species and other dwarf shrubs (e.g. Vaccinium uliginosum L., Empetrum nigrum subsp. hermaphroditum (Hagerup) Böcher). The ground cover consists of mosses and lichens. The area is pristine.

\section{Data collection}

In August 2015, we established study plots within three different forest types along an altitudinal gradient, starting at the current treeline and moving down slope. The forest types were defined based on the stand density according to Shiyatov et al. (2007). 

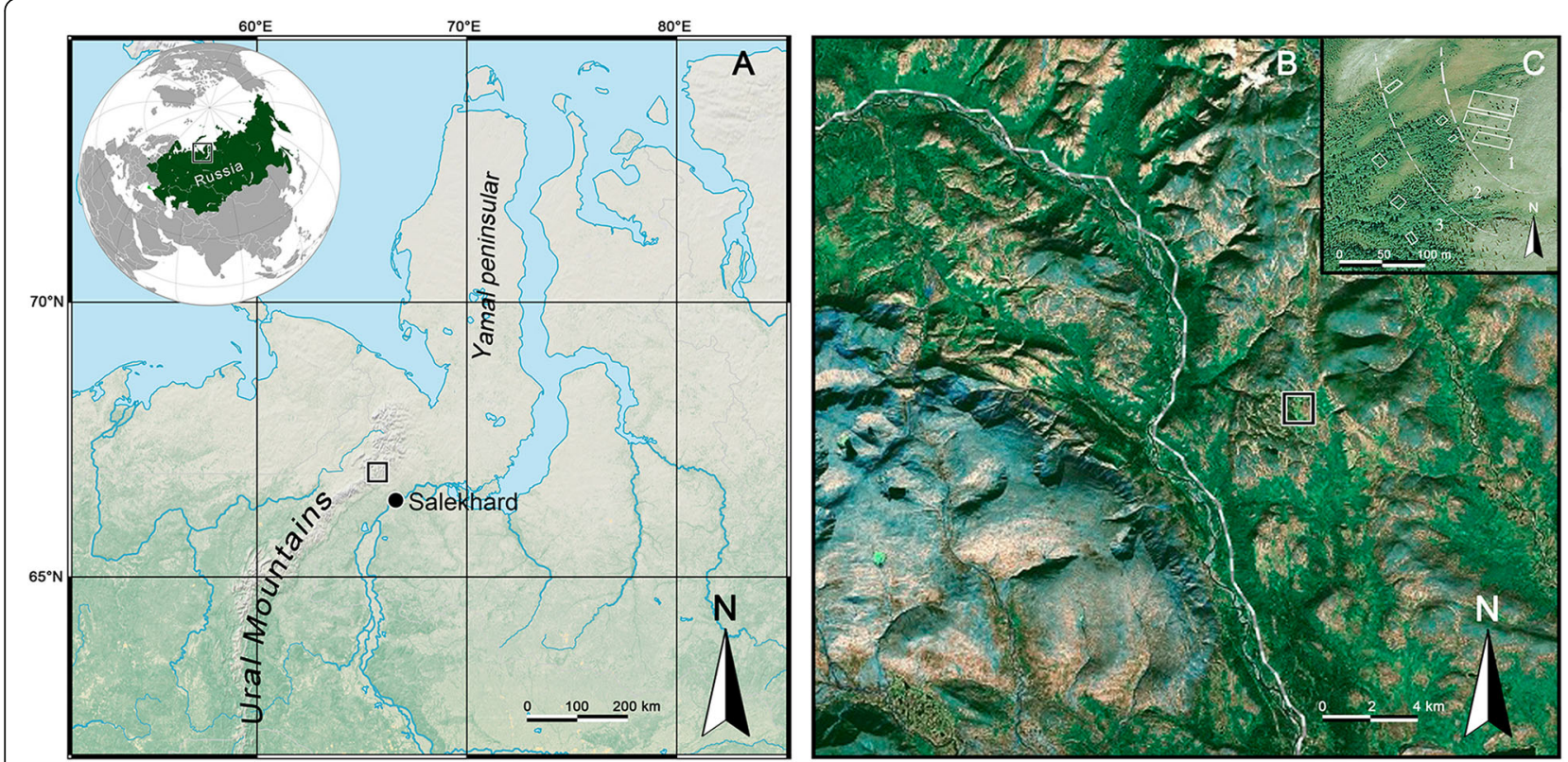

Fig. 1 Location of the study area (a and $\mathbf{b})$ and scheme of study plots establishment (c). The numbers indicate the types of forest (1 - Treeline, 2 - Open forest, 3- Closed forest)

Specifically, we defined the type Treeline as the stand with trees distances ranging between 20 and $50 \mathrm{~m}$ and average tree height $\leq 2 \mathrm{~m}$; the Open forest with distances between 7 and $20 \mathrm{~m}$, and the Closed forest with distances inferior of $7 \mathrm{~m}$ (Fig. 3).

At each forest area, we established 3 research plots that together contained at least 100 trees, thus with different size. The total area was $11,306 \mathrm{~m}^{2}$. The main characteristics of the forest types are presented in Table 1.
The current altitude position of each forest type was defined as the average altitude, measured at the center of three rectangular research plots.

\section{Dendrometric survey and tree-ring width measurements}

To assess the current state and reconstruct the stand structure in different periods of the twentieth century, we first assessed the position of all individuals (trees and saplings) within each plots with a GPS receiver (Garmin Oregon 650). Since all woody remnants on

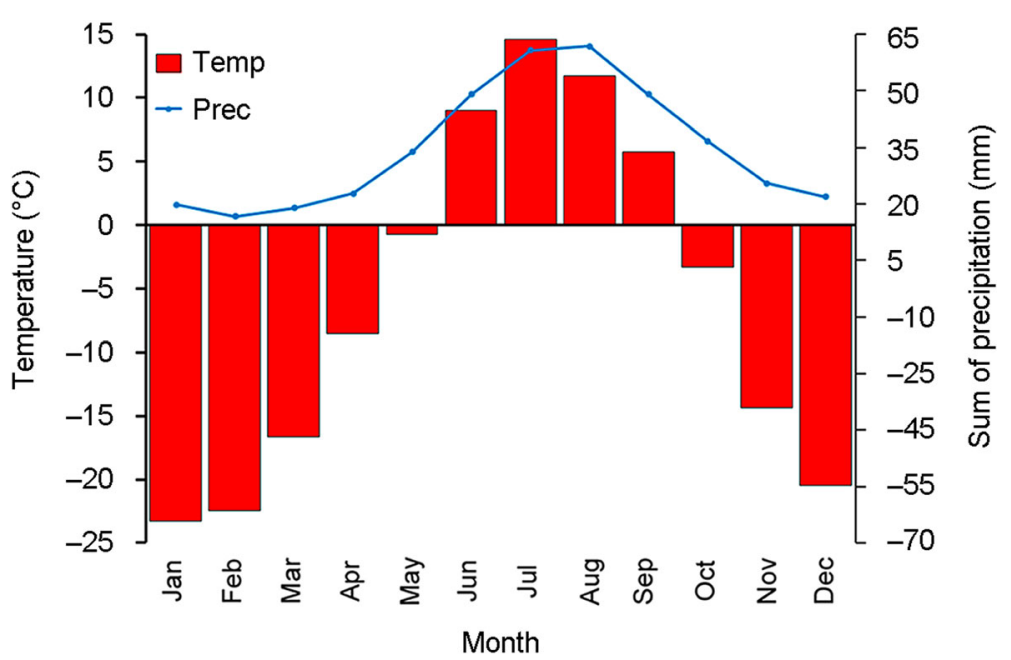

Fig. 2 Climadiagram for Salekhard weather station ( $66^{\circ} 32^{\prime} \mathrm{N}, 66^{\circ} 32^{\prime} \mathrm{E} ; 35 \mathrm{~m}$ a.s.l.; 1892-2015). Blue line and red columns are the long-term average sum of precipitation and average monthly temperature, respectively 


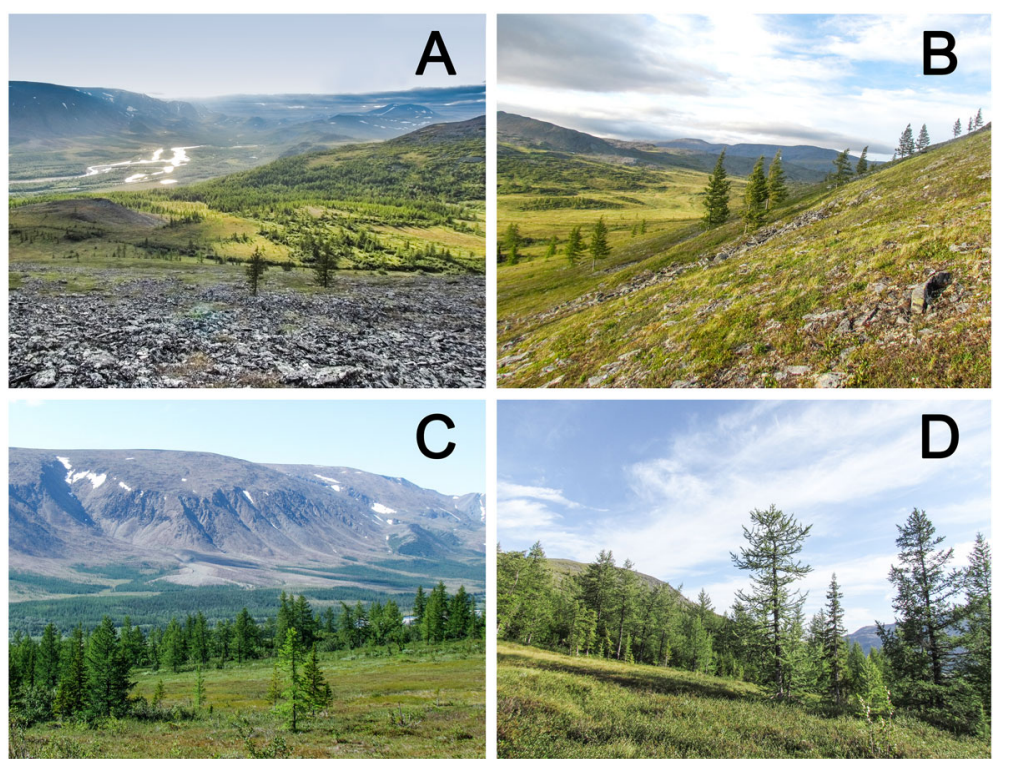

Fig. 3 Photos of treeline ecotone on the Slantsevaya Mountain. a General view, (b) treeline, (c) open and (d) closed forest

the sites were accounted, all trees, even those that died earlier, were included in our analysis. The phenomenon of mass mortality at the treeline mainly affects seedlings, since in the life of shoots, the first years are the most critical period, when they are especially sensitive to the effects of sharp fluctuations in temperature and humidity, and when the mortality is greatest. In total, 346 individuals were considered. Subsequently, we measured the height, base diameter, and crown projection of each individual. Height of tall trees $(>5 \mathrm{~m})$ was assessed with a digital rangefinder (accuracy $0.3 \mathrm{~m}$, TruPulse 200B) while a telescopic ruler (accuracy $1 \mathrm{~cm}$ ) was used for small trees. Stem perimeters and crown projections were measured using a measuring tape (accuracy $0.5 \mathrm{~cm}$ ).

Additionally, to determine age and annual growth, each individual with a stem diameter $>2-3 \mathrm{~cm}$ was cored using 5-mm increment borer (Haglöf, Sweden) at a height of up to $10 \mathrm{~cm}$. Smaller individuals were sawed at the ground level and then through every two centimeters of height to determine the local height-age growth

Table 1 Characteristics of the selected forest types along the altitudinal transect

\begin{tabular}{llll}
\hline & \multicolumn{2}{l}{ Forest types } \\
\cline { 2 - 4 } & Treeline & Open forest & Closed forest \\
\hline Altitude $(\mathrm{m}$ a.s.l.) & 310 & 280 & 260 \\
Number of plots & 3 & 3 & 3 \\
Total plot area $\left(\mathrm{m}^{2}\right)$ & 9451 & 860 & 995 \\
Stand density $\left(\right.$ trees.ha $\left.^{-1}\right)$ & 148 & 930 & 1166 \\
\hline
\end{tabular}

function. The obtained relationship served to refine age determination of trees $>2-3 \mathrm{~cm}$ in diameter (Niklasson 2002; Hagedorn et al. 2014).

All discs and cores (pre-mounted in a wooden holder) were cleaned with razor blades and whitened with wet chalk to increase the visibility of the tree-ring boundaries. The measurement of the wood cores and discs was carried out according to standard dendrochronological techniques (Cook and Kairiukstis 1990; Rinn 1996). Tree-ring width was measured using a binocular microscope above a moving measure table with an accuracy of $0.01 \mathrm{~mm}$ (LINTAB, F. Rinn SA, Heidelberg, Germany). Ring widths were recorded using the TSAP program v4 (www.rinntech.com). All samples were first visually cross-dated in TSAP and cross-dating quality checked using the program COFECHA (Holmes 1995) by matching the undated samples against the dated local larch chronology (Briffa et al. 2013). The sample depths and the statistical characteristics of the tree-ring series are presented in Appendix 1 and 2.

We defined the current treeline position as a stand with a canopy cover $\geq 0.07 \pm 0.01$ and an average height of trees $\leq 2 \mathrm{~m}$ and assumed that the same criterion was the same in the past. The reconstruction of the former treeline position has been carried out based on a retrospective assessment of the density of tree stands (Shiyatov 1986), as well as the age and morphometric characteristics of individual trees (height) on research plots. Using a dated tree ring series, the stem diameters of all trees were reconstructed yearly. The historical tree heights were reconstructed based on dependency between the actual 
heights and diameters of the stems. Treeline shift was calculated as the difference between the current and historical treeline position.

To study age-related trends in radial growth, trees (this analysis was performed only for larch due to insufficient number of spruce models) were divided into four age groups that included at least 15 individuals, namely $1-30,31-60,61-90$ and $91-120$ years.

To study climate-growth relationships, ring-width chronologies for each forest type were assessed by combining individual age-detrended timeseries of each forest type into a site chronology using a biweight robust mean. Age-detrending were performed individually with a $60 \%$ cut-off at half-length of the series cubic spline (Cook and Peters 1981) using ARSTAN (Cook and Krusic 2006). Calculations of radial growth responses to climate (monthly temperature and precipitation of Salekhard meteo station) were conducted for each forest type using the bootstrapped response function of DENDROCLIM 2002 (Biondi and Waikul 2004). This statistical procedure allows estimating the relative contribution of different climate variables (e.g. air temperature and precipitation) using regression coefficients, by constructing a multiple regression model describing the variability of tree growth indices (Fritts 1976). A 95\% confidence level was used to determine the statistical significance within a 12-month window spanning from previous September to current August. All statistical analyses were conducted using STATISTICA 8.0. Kruskal-Wallis criteria for independent groups was used to examine differences of morphometric parameters and trees ages between elevation zones.

\section{Biomass calculation}

Allometric functions between tree biomasses and stem base diameters were assessed using trees from outside the research plots but in similar forest types.
In total 33 model trees were felled and sectioned to collect stem disks at the stem base, at $0.25 \mathrm{~m}$ and breast height $(1.3 \mathrm{~m})$, and then at every subsequent meter in stem height. Stems fresh mass was determined with a hand weight scales with $50 \mathrm{~g}$ accuracy. The crown was divided into three equal sections, and from each section, the sample of the middle section was taken for biomass assessment. The fresh mass of the leafless branches, needles and cones were separately determined with a digital weight scales with an accuracy of $0.01 \mathrm{~g}$. All the wood, branches, needles, and cones were then oven-dried at $106{ }^{\circ} \mathrm{C}$ until a stable weight and the dry masses of all the components were calculated for each tree and used to assess the allometric functions. These relations (Fig. 4), combined with the dependencies between the actual heights and stem diameters, were then combined with the tree-ring width measurements to assess biomass accumulation over time. The stem diameters of all examined trees were reconstructed at each decade of the twentieth century considering geometric relations (see Bakker 2005), and according to the following formula:

$$
D_{n}=\left(R_{n} / R_{\text {final }}\right) \times D_{\text {final }}
$$

where $D_{n}$ is the computed tree diameter in a given year; $R_{n}$ is the radius of the correponding annual ring; $R_{\text {final }}$ is the current tree radius; and $D_{\text {final }}$ is the current tree diameter.

Since the rate of biomass growth results from both radial growth increase and establishment of new trees, we analysed the influence of temperature and precipitation on biomass. May-August climatic variables were nominally attributed to the "growth period", while the rest 8 months - to the "dormant period". Spring and autumn
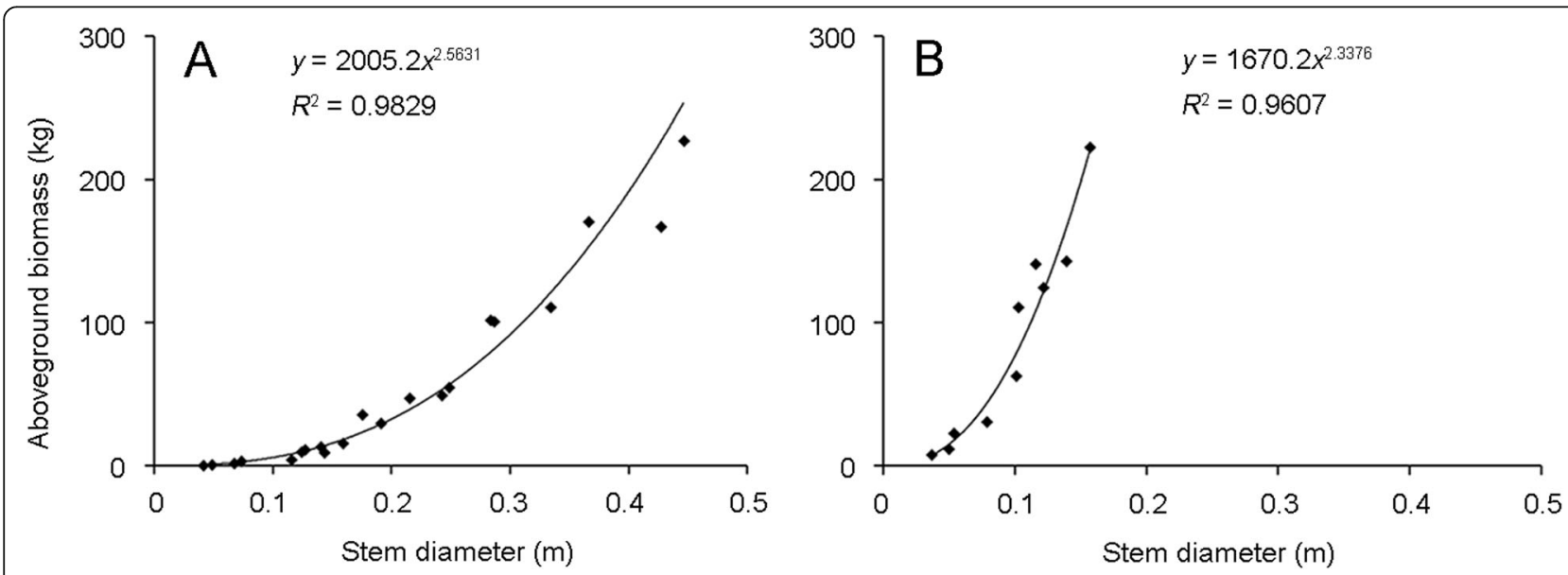

Fig. 4 Relation between aboveground biomass and stem base diameter for (a) larch and (b) spruce 
phenophases (due to their short duration and variability of the beginning and end of vegetation) were not identified.

Pearson's correlation was used for annual resolution data. Averaged over decades values were analyzed with Spearman rank correlation.

\section{Results}

\section{Forest establishment}

Siberian larch dominated at all altitudinal levels, accounting for more than $70 \%$ of the tree stems. When moving along the altitude gradient, the percentage of Siberian spruce in the tree stands decreased slightly: from $26 \%$ at the treeline to $19 \%$ in the closed forest. The number of living trees per hectare showed an eightfold increase (from 148 trees.ha ${ }^{-1}$ at the treeline to 1166 trees.ha ${ }^{-1}$ in the closed forest). Similar proportions were observed regarding the number of saplings (individuals less than $2 \mathrm{~m}$ high) since Siberian larch saplings accounted for $69 \%$ of the total. The ratio of larch and spruce saplings $(70 \% / 30 \%)$ suggest further preservation of the share of these species in the tree stand. Results also indicated a large presence of saplings (up to 110 PCs.ha ${ }^{-1}$ ) at the upper part of the treeline ecotone. No dead seedlings nor saplings where observed.

The analysis of the age structure (Fig. 5) showed that modern stands in the treeline ecotone was formed in the last 1.5 centuries. The mass establishment of trees of both species is dated to the beginning of the twentieth century, before which time only $17 \%$ of the currently living trees were represented. In particular, $91 \%$ of spruce and $79 \%$ of larch appeared in the last 115 years. The stands were mostly composed by young trees especially in the upper part of the treeline ecotone. The afforestation at the treeline mostly occurred in the last decades of the twentieth century, as indicated by the important number of saplings. Indeed, the maximum age of the trees did not exceed 120 years, and there were only a few old trees. However, the trees establishment in the open forest occurred earlier in the second half of the twentieth century, and the larch and spruce trees at this level had the same average age. In the closed forest, the average age of the trees was $>100$ years. Individuals under 30 years of age were almost absent, and only few individuals were between 30 and 60 years old. The maximum age of the trees exceeded 250 years. Hence, the displacement of the treeline by $50 \mathrm{~m}$, which occurred in the last 100 years, is indicated by a large amount of saplings in the upper part of the ecotone, the absence of saplings in the stands formed earlier, and a decrease in the average and maximum age of the trees up the altitude gradient.

\section{Growth dynamics}

The changes in the main dendrometric characteristics at each forest types are shown in Table 2 and

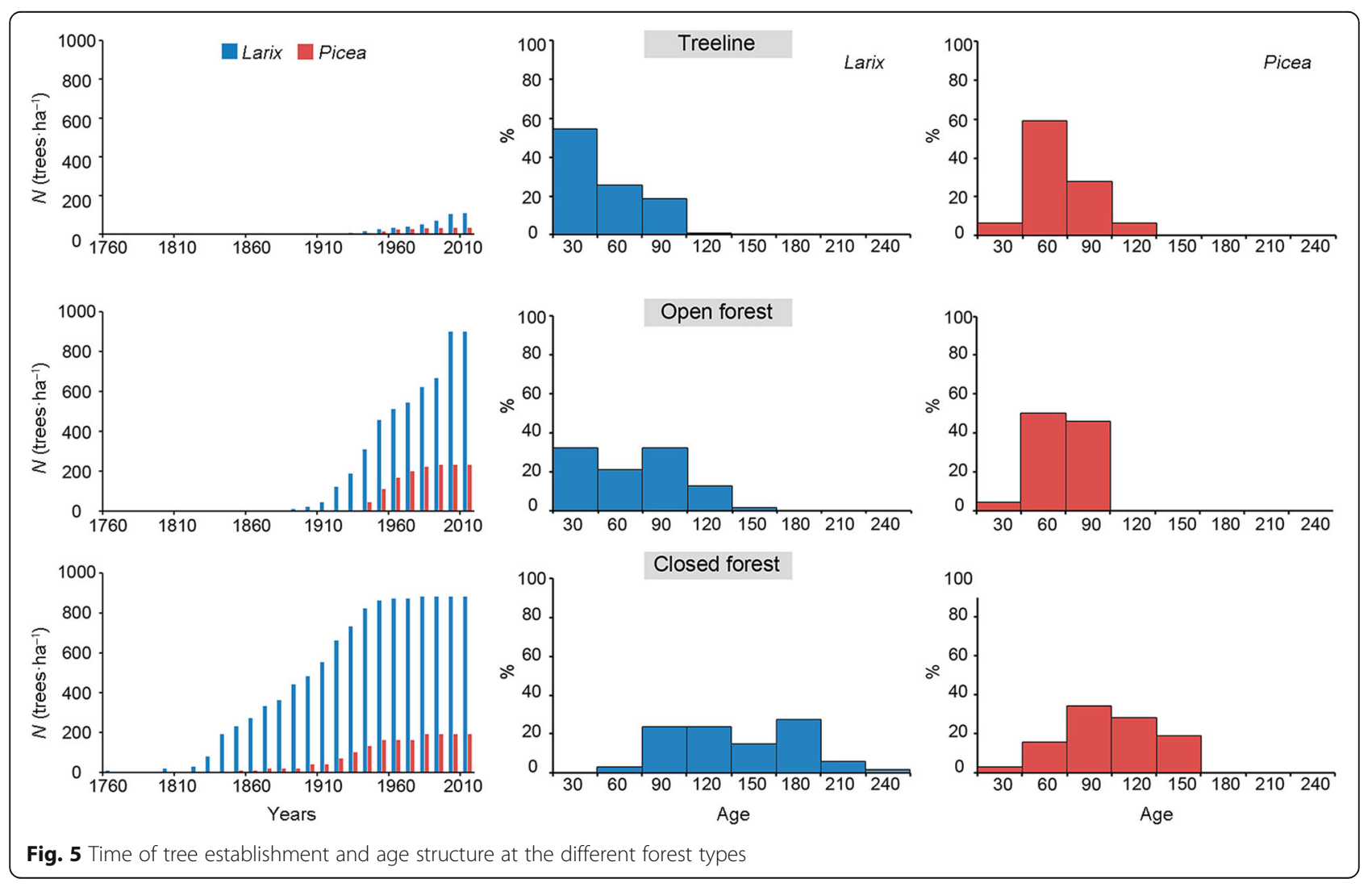


Table 2 Mean and standard errors of the main dendrometric parameters at the different forest type, differentiated by species

\begin{tabular}{|c|c|c|c|c|c|c|}
\hline & \multicolumn{6}{|c|}{ Forest type } \\
\hline & \multicolumn{2}{|l|}{ Treeline } & \multicolumn{2}{|c|}{ Open forest } & \multicolumn{2}{|c|}{ Closed forest } \\
\hline & Larch & Spruce & Larch & Spruce & Larch & Spruce \\
\hline Stand composition (\%) & 74 & 26 & 75 & 25 & 81 & 19 \\
\hline Stem base diameter $(\mathrm{cm})$ & $8.8 \pm 0.9$ & $6.0 \pm 0.8$ & $12.7 \pm 1.3$ & $9.0 \pm 1.3$ & $27.1 \pm 1.2$ & $11.0 \pm 1.1$ \\
\hline Stem height (m) & $2.5 \pm 0.2$ & $1.5 \pm 0.2$ & $3.8 \pm 0.3$ & $3.1 \pm 0.3$ & $11.7 \pm 0.5$ & $4.5 \pm 0.4$ \\
\hline Age (years) & $36 \pm 3$ & $52 \pm 3$ & $51 \pm 3$ & $53 \pm 3$ & $125 \pm 4$ & $82 \pm 5$ \\
\hline
\end{tabular}

Appendix 3. These data indicate that there was a gradual increase in the average tree size along the transition from the treeline to the closed forest. The stem diameter, height, and age of the trees increased 1.6-4.7 times, but were more pronounced for larch (3.1-4.7 times) than for spruce (1.5-3 times).

Considering the tree-ring data, in recent decades there has been a sizeable increase in radial growth at all forest types, both for larch and spruce (Figs. 6 and 7). Relatively weak growth since the first half of the twentieth century was replaced by a significant acceleration after the 1950s. At the same time, after a sudden increase, the growth of larch stabilized, and the growth of spruce continued to rise. However there are some differences between the forest types. At the treeline, the trend in radial growth of the lower age group (1-30 years) shows an overall negative trend. This finding is connected to the age-related characteristics high growth trend at very young ages. Indeed, an opposite trend with increasing ring width has started after 2000. The 31-60-year-old trees at the treeline and in the open forest showed an increase in growth in the 1980s and which also become important after 2000. At the same time, trees of the same age in the closed forest only showed stable growth with a downward trend in radial growth, since they grow under the pressure of older trees and their growth is certainly influenced by competition for light and nutrients. In contrast, the dominant trees belonging to the 61-90 and the 91-120 age groups, show a strong increase in the growth rate since the 1970s. The absolute values of the larch and spruce

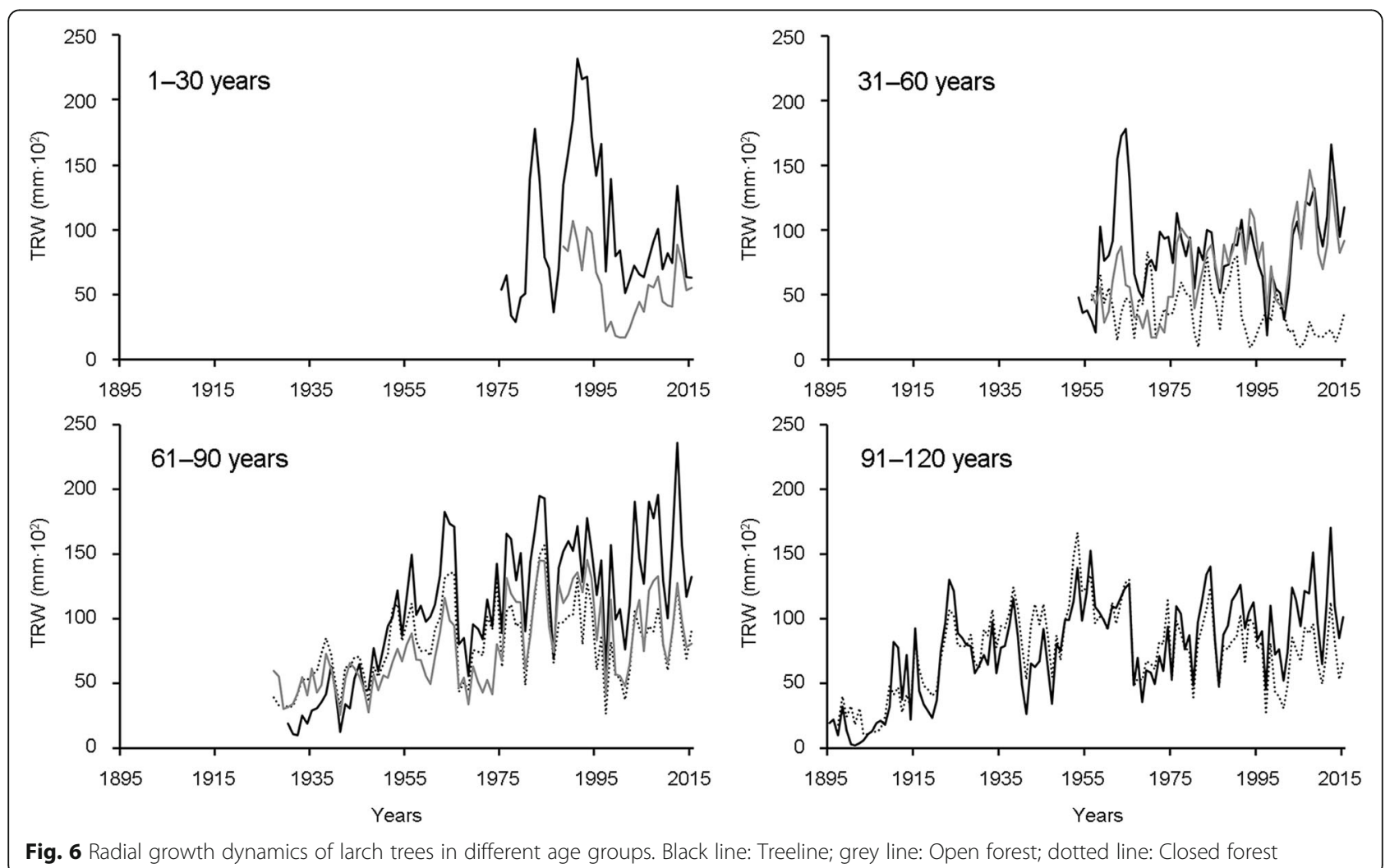


A

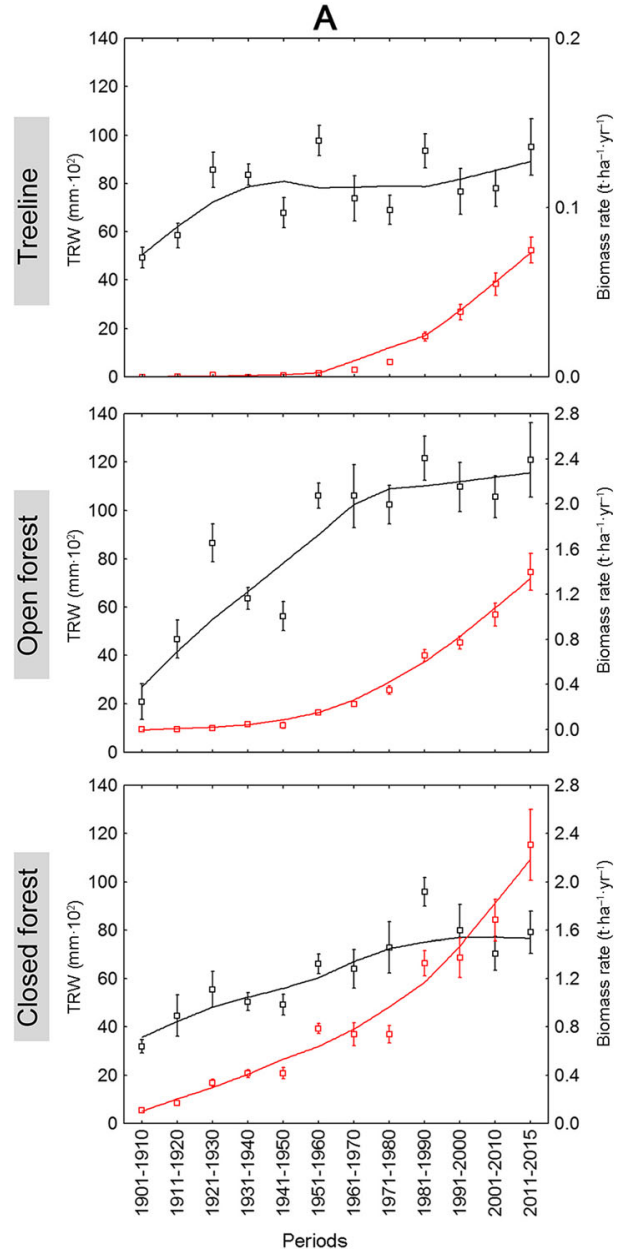

B

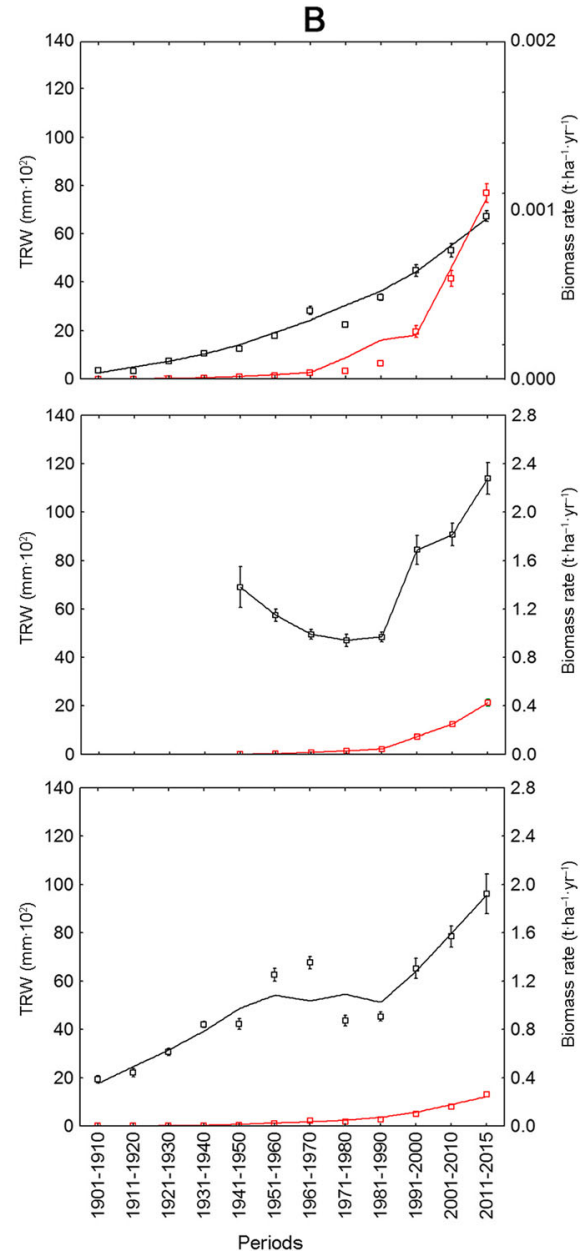

Fig. 7 Radial growth (black) and rate of biomass accumulation (red) of larch (a) and spruce (b) at different forest type (smoothed by decades)

growth were significantly higher in the open forest compared to other levels $(F=20.423, p<<0.001)$, $(F=3.75$, $p=0.047)$, respectively.

\section{Biomass accumulation}

Since stand biomass accumulation summarizes both the processes of growth increment and tree recruitment and mortality (Gower et al. 1996; Pan et al. 2013), the changes in climatic conditions occurring in the second half of the twentieth century led to multiple increases in the rates of biomass accumulation. Since mortality has almost not been observed (only 10 dead tree trunks were found in our sample areas) and since these arctic conditions (permafrost, short vegetation season, low rate of wood decomposition) favour the preservation of tree remains for hundreds of years (Yatskov et al. 2003; Mazepa 2005), mortality was not included in our analysis.

Changes in the stand structure and radial growth of the trees resulted in significant changes in the stock and rate of aboveground biomass accumulation within the treeline ecotone (Table 3, Fig. 6).

In the early twentieth century in the upper part of the ecotone, the stock of aboveground biomass was near zero. The average rate of biomass accumulation between 1900 and 1950 was very low at $0.0003 \mathrm{t} \cdot \mathrm{ha}^{-1}$ per year. After 1950, this value increased by 86 times.

Table 3 Stock and rate of accumulation of the aboveground biomass at the different forest types during the 20th century

\begin{tabular}{llll}
\hline Year & \multicolumn{3}{l}{$\begin{array}{l}\text { Stock of aboveground biomass }\left(\mathrm{t} \cdot \mathrm{ha}^{-1} \text { ) and }\right. \\
\text { (larch proportion (\%)) in different forest types }\end{array}$} \\
\cline { 2 - 4 } & Treeline & Open forest & Closed Forest \\
\hline 1900 & 0 & $1.13 \times 10^{-5}(100)$ & $2.45(97)$ \\
1950 & $0.02(99)$ & $0.93(99)$ & $17.09(99)$ \\
2000 & $0.80(100)$ & $24.89(90)$ & $69.34(96)$ \\
2015 & $1.73(99)$ & $46.72(85)$ & $100.67(94)$ \\
Average rate of biomass & 0.02 & 0.40 & 0.85 \\
accumulation from & & & \\
1900 to 2015 (t.ha $\left.{ }^{-1} \cdot \mathrm{yr}^{-1}\right)$ & & & \\
\hline
\end{tabular}


At the moment, the aboveground biomass is $1.12-2.86$ t.ha ${ }^{-1}$. The contribution of spruce to the stock of the stand biomass was and remains irrelevant since for the entire period it only increased from 0 to $1.3 \%$.

In the open forest the rate of biomass accumulation in the first half of the twentieth century was $0.014 \cdot \mathrm{tha}^{-1} \cdot \mathrm{yr}^{-1}$. By 2015, the annual production increased by 59 times. The current aboveground stand biomass of the three research plots ranged 15.67-62.82 tha ${ }^{-1}$, with spruce contribution averaging $15 \%$.

In the closed forest stands, which were almost formed in the nineteenth century, the aboveground stand biomass at the beginning of 1900 was 2.45 t.ha ${ }^{-1}$, with annual increments of $0.029 \mathrm{t} \cdot \mathrm{ha}^{-1} \cdot \mathrm{yr}^{-1}$. Over the next 115 years, the rate of biomass accumulation increased by 39 times reaching now an aboveground biomass stock of $94.22-110.11 \mathrm{t} \cdot \mathrm{ha}^{-1}$ with an average annual growth rate of $1.14 \mathrm{t}^{\mathrm{h}} \mathrm{ha}^{-1} \cdot \mathrm{yr}^{-1}$. The contribution of spruce in 115 years increased by only $3 \%$.

At the treeline, the change in the rate of biomass accumulation of larch during the twentieth century was more associated with the establishment of new trees $(r=0.94$, $p<<0.01$, Table 4) while at other forest types and for spruce the rate of biomass accumulation was mostly associated to radial growth.

\section{Association to climate}

According to the meteorological data from Salekhard, significant warming and moistening occurred over the last 135 years and which are still ongoing (Fig. 8). In particular, both growth and dormant periods temperatures increased by $1.7^{\circ} \mathrm{C}$ since 1900 . Meanwhile, May-August precipitation increased by $49 \mathrm{~mm}$ (from 175 to $224 \mathrm{~mm}$ ), and by $103 \mathrm{~mm}$ in September-April (from 135 to $238 \mathrm{~mm}$ ).

Trees establishment at treeline correlated positively with precipitation of both periods (Table 5). For spruce, this relationship was maintained also for the closed forest. Regarding temperature, a relationship with MayAugust temperature has been detected only for the larch trees at the treeline.

Table 4 Correlation between rate of biomass accumulation and radial growth (annual data)/tree establishment (averaged over decades) for the tree forest types differentiated by species

\begin{tabular}{|c|c|c|c|c|c|c|}
\hline \multirow[b]{3}{*}{ Species } & \multicolumn{6}{|c|}{ Forest type } \\
\hline & \multicolumn{2}{|l|}{ Treeline } & \multicolumn{2}{|c|}{ Open forest } & \multicolumn{2}{|c|}{ Closed forest } \\
\hline & Larch & $\overline{\text { Spruce }}$ & Larch & $\overline{\text { Spruce }}$ & Larch & Spruce \\
\hline Tree-ring width & 0.23 & $0.86^{*}$ & $0.63^{*}$ & $0.70^{* *}$ & $0.59 *$ & $0.82^{*}$ \\
\hline Tree establishment & $0.94^{* * *}$ & -0.11 & 0.49 & -0.92 & -0.64 & -0.40 \\
\hline
\end{tabular}

The response function analysis comparing the annual tree-ring growth of the two species showed no significant relationships with monthly precipitation (Fig. 9). However, both species showed a positive response to June-July temperature. Responses were stronger for July and for larch than for spruce. A significant increase in the May and June temperatures correlation might also indicate an earlier start of the growing season.

Linkage between the rate of biomass accumulation and main climatic variables indicated that precipitation during dormant period had a weak positive effect but the most important climatic factor determining the biomass accumulation was growth season temperatures. The June and July temperatures were significant for larch and the May and June temperatures were significant for spruce (Table 6).

\section{Discussion}

Our study showed that the forest-tundra intersection at the Polar Urals has been undergoing important changes during the twentieth century. Forests expanded upwards with more than $90 \%$ of trees established during the last 115 years. Tundra areas which were treeless at the beginning of the twentieth century are now covered by dense forest (150-900 tree$\mathrm{s} \cdot \mathrm{ha}^{-1}$ ). The big number of saplings in the upper part of treeline implies that forest is currently expanding. In particular, thanks to our relation with long term climatic data, we suggest that the forest expansion was mainly caused by changes in the moisture regime and, to a lesser extent, by temperature. On one hand, the increase of 1.15 times of summer precipitation facilitated the mass emergence and better survival of seedlings which is consistent with the data for other areas of the Polar Ural (Mazepa 2005; Devi et al. 2008; Kukarskih et al. 2018) and northern Eurasian treelines (Vaganov et al. 1996; Briffa et al. 1998; Esper et al. 2002; Matskovsky 2016). However, the lack of a strong relationship is related to the fact that the soil moisture content is usually sufficient for tree growth (Pan et al. 2013). On the other hand, the increase in precipitation during the dormant period by 1.25 times contributed to the survival of saplings, affecting plants through changes in snow depth and soil temperature. This is consistent with observation of Shiyatov (1967), who suggested that the main limiting factor for the emergence of seedlings in the Polar Urals is the humidity of the substrate in the first years of the life since 1-2-year-old seedlings have insufficient rooting and low water-holding capacity. The influence of winter conditions (snow cover, air temperature and wind speed) on trees 


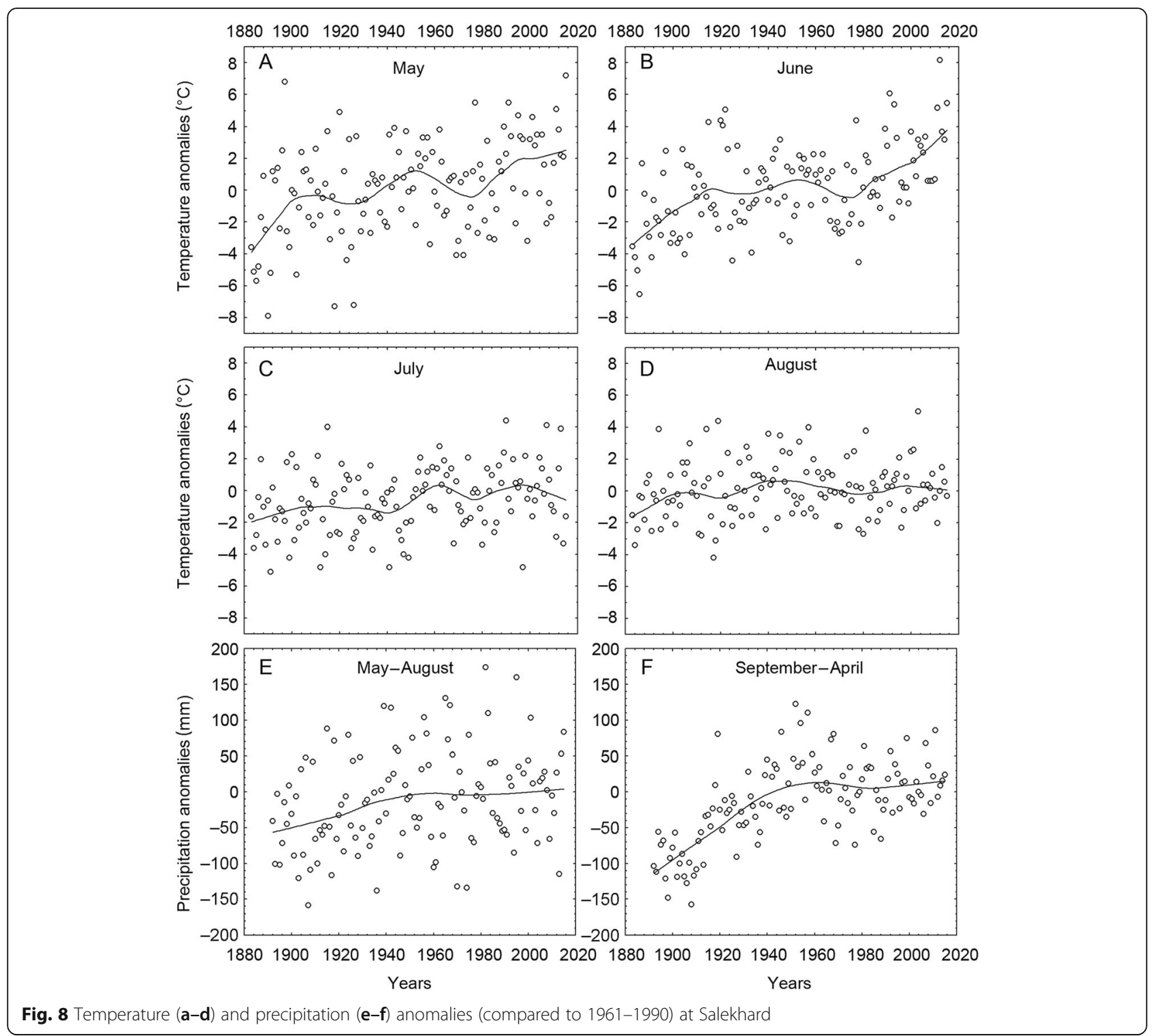

Table 5 Spearman rank correlation between the frequency of tree appearance and seasonal climatic variables

\begin{tabular}{|c|c|c|c|c|c|c|}
\hline & \multicolumn{6}{|c|}{ Forest type } \\
\hline & \multicolumn{2}{|c|}{ Treeline } & \multicolumn{2}{|c|}{ Open forest } & \multicolumn{2}{|c|}{ Closed forest } \\
\hline & Larch & Spruce & Larch & Spruce & Larch & Spruce \\
\hline \multicolumn{7}{|l|}{ Temperature } \\
\hline Growth period (5-8) & $0.93^{*}$ & 0.55 & 0.57 & 0.33 & -0.55 & -0.28 \\
\hline Dormant period (p9-4) & 0.51 & 0.19 & 0.54 & -0.01 & 0.13 & 0.32 \\
\hline \multicolumn{7}{|l|}{ Precipitation } \\
\hline Growth period (5-8) & $0.78^{*}$ & $0.73^{*}$ & 0.51 & $0.67^{*}$ & -0.30 & -0.11 \\
\hline Dormant period (p9-4) & $0.86^{*}$ & $0.71^{*}$ & 0.60 & $0.63^{*}$ & -0.46 & -0.16 \\
\hline
\end{tabular}




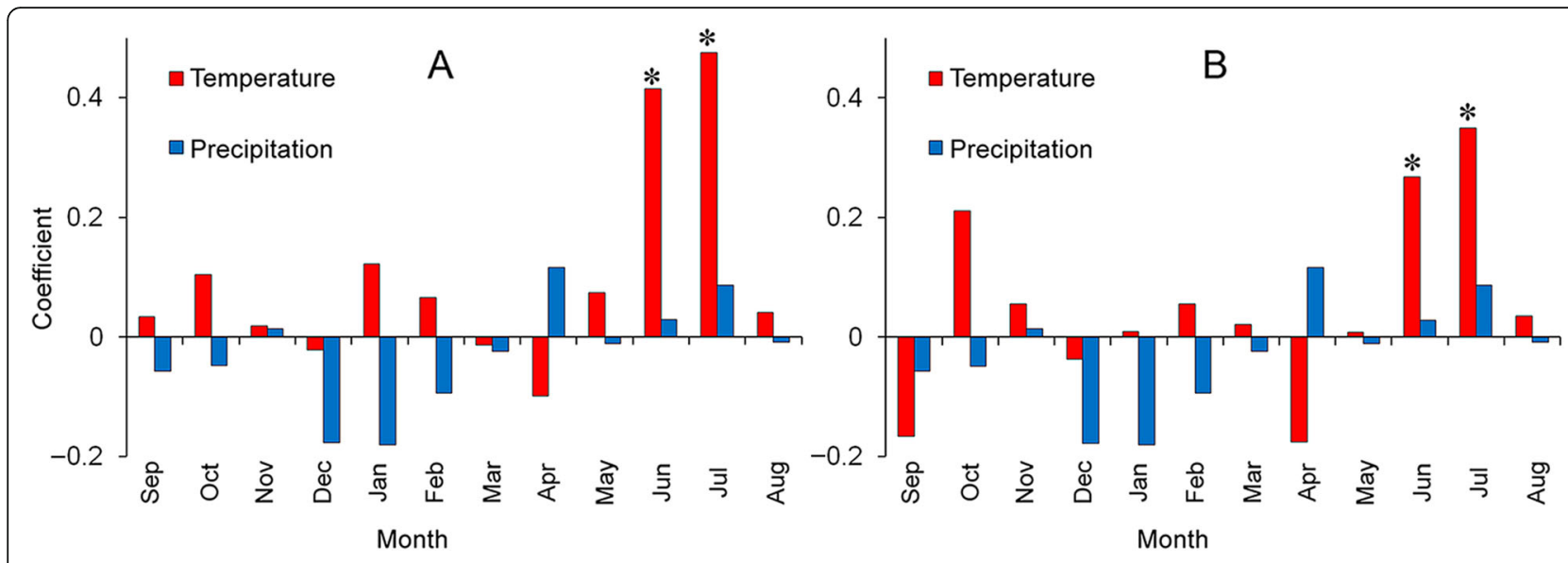

Fig. 9 Climate-growth correlation for larch $(\mathbf{a})$ and spruce $(\mathbf{b})$. Blue $=$ precipitation, red $=$ temperatures; ${ }^{*}-$ significant at $p<0.01, N=123$

recruitment and survival can affect soil freezing and cause shoots desiccation (Gorchakovsky and Shiyatov 1978; Lavoie and Payette 1992; Weisberg and Baker 1995; Kullman and Engelmark 1997; Holtmeier and Broll 2007; Hagedorn et al. 2014; Renard et al. 2016; Davis and Gedalof 2018; Frei et al. 2018; Grigorieva and Moiseev 2018).

Our observations of treeline upshift of $50 \mathrm{~m}$ during the last century are supported by large-scale studies of the Polar Urals using GIS technology and repeated photograph analysis. These studies have shown a treeline upshift by $35-80 \mathrm{~m}$ since the 1920 s and which was accompanied by an increase in stand density (Shiyatov et al. 2005; Shiyatov et al. 2007; Shiyatov and Mazepa 2015). These rates are similar to forest boundary expansion of $30-60 \mathrm{~m}$ during the last $60-80$ years observed over the globe (Lavoie and Payette 1992; Wardle and Coleman 1992; Lloyd and Graumlich 1997; Moiseev 2002; Kullman and Öberg 2009; Kharuk et al. 2010, 2017; Kirdyanov et al. 2012).

In parallel with the establishment of new individuals, the vast majority of trees within all forest types have showed an increase of radial growth. These changes are evident in all age groups, including aged trees. The general increasing trend of radial growth in recent decades indicates the predominant influence of common external factors on tree growth, as well as the benefits of modern climate change for the growth of tree plants. Most researchers attribute this to an increase in average summer temperature and precipitation, as these factors determine the intensity of physiological processes in plants (Taylor 1995; Esper et al. 2002; Körner and Paulsen 2004; Körner 2012; Keane et al. 2018; Kukarskih et al. 2018). The analysis of the climatic-growth relationships with the data of Salekhard weather station clearly indicated that most of the increases are related to early summer temperatures (June $+0.27^{\circ} \mathrm{C}$ per decade since 1901). Another positive effect of temperatures is the promotion of tree growth at the beginning of growing season. The influence of May conditions on the evergreen spruce trees is associated with an earlier onset of photosynthesis, while June air temperatures has common positive role for

Table 6 Pearson's correlation between rate of biomass accumulation and selected climatic variables

\begin{tabular}{|c|c|c|c|c|c|c|c|}
\hline & \multicolumn{2}{|l|}{ Precipitation } & \multirow{2}{*}{$\begin{array}{l}\text { Temperature } \\
\text { Growth period (5-8) }\end{array}$} & \multirow[b]{2}{*}{ May } & \multirow[b]{2}{*}{ June } & \multirow[b]{2}{*}{ July } & \multirow[b]{2}{*}{ August } \\
\hline & Growth period (5-8) & Dormant period (p9-4) & & & & & \\
\hline \multicolumn{8}{|l|}{ Larch } \\
\hline Treeline & 0.07 & 0.19 & $0.42^{*}$ & 0.29 & $0.47^{*}$ & $0.30^{*}$ & 0.01 \\
\hline Open forest & 0.12 & $0.29^{*}$ & $0.45^{*}$ & $0.30^{*}$ & $0.48^{*}$ & $0.31^{*}$ & 0.05 \\
\hline Closed forest & 0.15 & $0.42^{*}$ & $0.52^{*}$ & 0.27 & $0.50^{*}$ & $0.42^{*}$ & 0.05 \\
\hline \multicolumn{8}{|l|}{ Spruce } \\
\hline Treeline & 0.09 & $0.23^{*}$ & $0.38^{*}$ & $0.32^{*}$ & $0.44^{*}$ & 0.13 & 0.03 \\
\hline Open forest & -0.00 & -0.01 & $0.37^{* *}$ & $0.30^{* *}$ & $0.49^{* *}$ & 0.11 & 0.01 \\
\hline Closed forest & 0.14 & $0.32^{* *}$ & $0.44^{*}$ & $0.35^{*}$ & $0.46^{*}$ & 0.21 & 0.02 \\
\hline
\end{tabular}


both tree species, as it coincides with the beginning of active tree growth (Rossi et al. 2007, 2008).

Advancing the forest treeline and increasing of stand's density may further alter the energy balance of new forested areas (Körner 2012; de Wit et al. 2014; Schwaab et al. 2015) by increasing C sequestration in plants and soils (Devi et al. 2008; Kammer et al. 2009). We observed that biomass stocks steadily increased by $39-86$ times during the last 50 years, especially in the upper and middle parts of the ecotone. At the upper level, biomass accumulation was mainly associated with new tree's establishment. However, the relevance of this process decreases with altitude while the role of radial growth to the production process increases. These observations partially contrasts with studies from other subarctic regions that also have shown a clear increase in stand productivity in the second half of the twentieth century, but with a recent decline in the accumulation rate attributed to stand aging (Myneni et al. 1997; Houghton 2005; Bunn et al. 2007).

Thus, our investigation show that observed changes of climatic conditions (an increase in precipitation in the dormant period and an increase in the average temperatures of the growth period in the absence of strong disruptive factors) had a multiplier effect on the growth and productivity of the examined treeline communities. Such a predictive tool can also assist in estimating potential future changes of treeline position. Taking into account local biotic and abiotic factors and processes the obtained patterns can be applied for entire upper treelines at the Polar Urals.

\section{Conclusion}

The present work for the first time quantified with annual resolution and for more than a century the impact of ongoing climate change on stand expansion, growth and productivity of a Polar Urals treeline ecotone, supporting numerous studies indicating the rapid shift of upper treelines. In particular we observed that the treeline moved $50 \mathrm{~m}$ upward and became denser. The long-term biomass assessment presented here provided information largely compatible with stand dynamic and tree-growth changes observed at the treeline ecotone at the Polar Urals during the last century. Our results also showed that the rate of afforestation, tree-ring growth, and biomass accumulation unidirectionally grew during the twentieth century and continue to accrue to the present time. These changes are driven by climate change mechanism, whereby the leading factors are the significant increase in early growth season temperatures and precipitation of the dormant period.

\section{Appendix 1}

Table 7 Statistical characteristics of tree-ring series

\begin{tabular}{lll}
\hline & Larch & Spruce \\
\hline Number of trees & 263 & 83 \\
Period & $1766-2015$ & $1851-2015$ \\
Ring width Mean \pm std. err. $(\mathrm{mm})$ & $0.81 \pm 0.47$ & $0.48 \pm 0.29$ \\
Mean sensitivity & 0.41 & 0.33 \\
Series intercorrelation & 0.65 & 0.41 \\
First order autocorrelation & 0.64 & 0.72 \\
\hline
\end{tabular}

\section{Appendix 2}

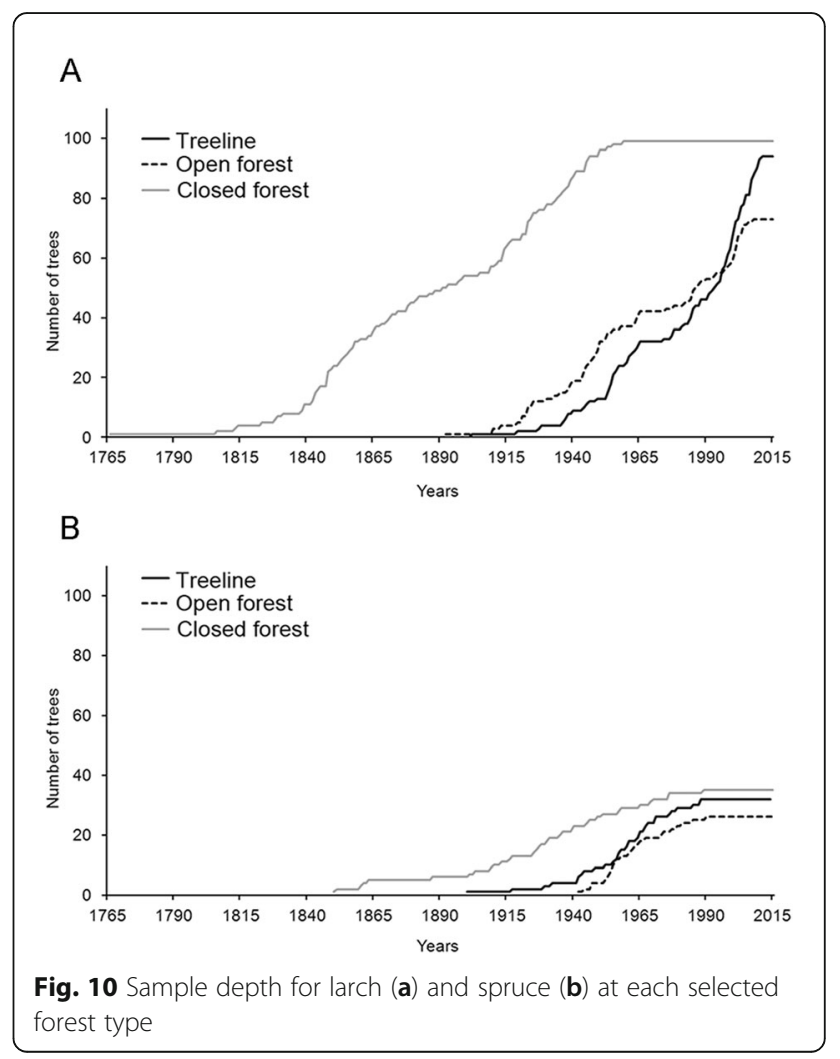




\section{Appendix 3}
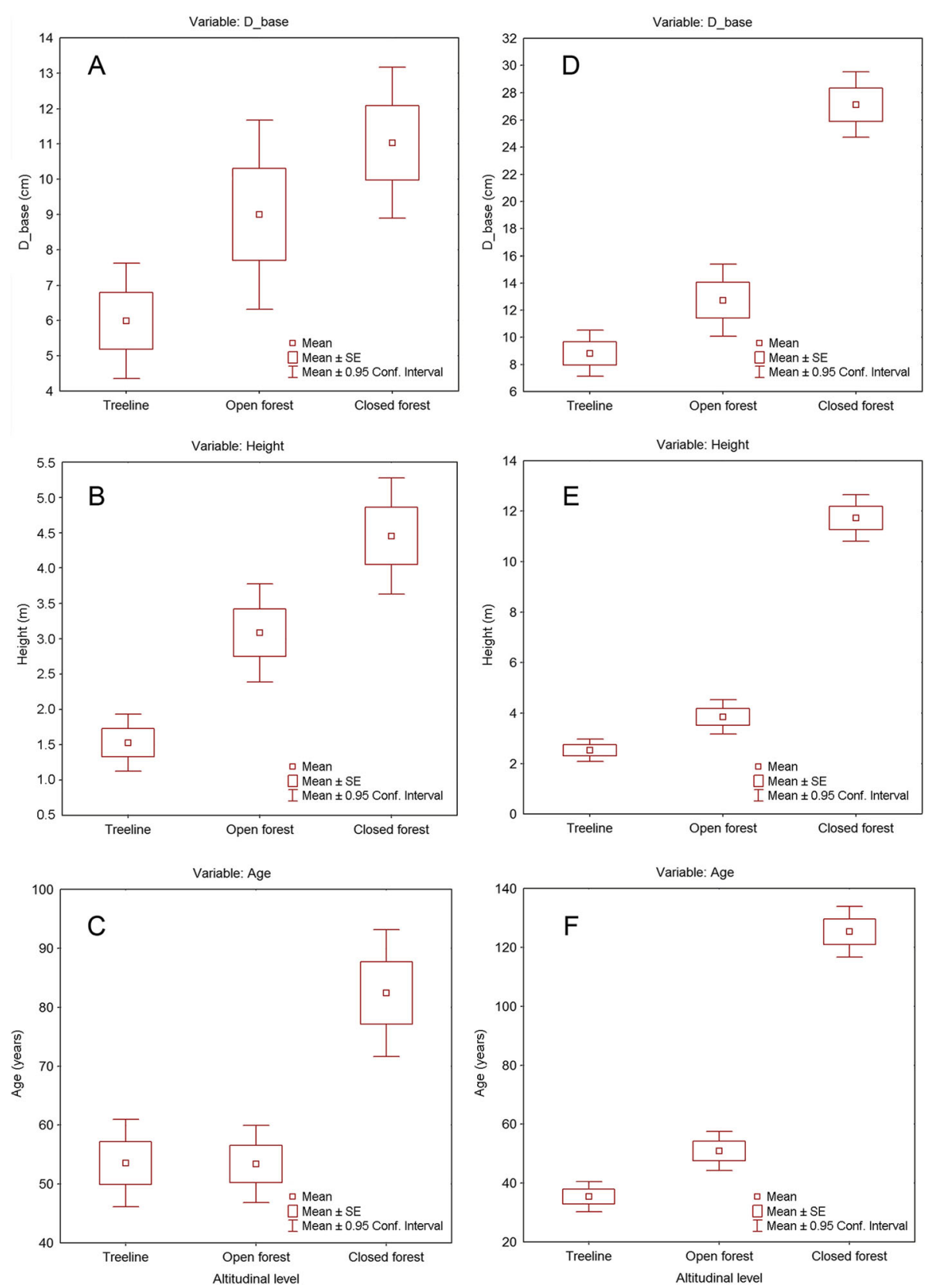

Fig. 11 Kruskal-Wallis ANOVA and median test for dendrometric parameters of spruce $(\mathbf{a}, \mathbf{b}, \mathbf{c})$ and larch $(\mathbf{d}, \mathbf{e}, \mathbf{f})$ at each forest type 


\section{Abbreviations}

$m$ a.s.l.: Meters above sea level; TRW: Tree-ring width; TSAP: Time Series and Analysis Program

\section{Acknowledgments}

We express our gratitude to Dr. Pavel Moiseev for constructive discussion on earlier version of the manuscript, as well as to Mr. Alexander Zubkov for his contribution during field survey. We thank Dr. Patrick Fonti for language editing and proofreading.

\section{Authors' contributions}

All co-authors performed the fieldwork. V. M, N.D., and V.K. measured the tree ring with, carried out the biomass calculation and interpreted the results. N.D. and V.K. wrote the manuscript. All authors read and approved the final manuscript.

\section{Funding}

N.D., V.K., A.G., and A.G. were supported by the Russian Science Foundation (Grant No. 17-14-01112). V.M. was supported by the Russian Foundation of Basic Research (Grant No. 19-05-00756). Data collection was partly performed within the frameworks of a state contract with the Institute of Plant and Animal Ecology, Ural Branch, Russian Academy of Sciences.

\section{Availability of data and materials}

The datasets used during the current study are available from the

corresponding author on reasonable request.

\section{Ethics approval and consent to participate}

Not applicable.

\section{Consent for publication}

Not applicable.

\section{Competing interests}

The authors declare that they have no competing interests.

Received: 12 April 2019 Accepted: 21 January 2020

Published online: 03 February 2020

\section{References}

Babst F, Bouriaud O, Alexander R, Trouet V, Frank D (2014) Toward consistent measurements of carbon accumulation: a multi-site assessment of biomass and basal area increment across Europe. Dendrochronologia 32:153-161. https://doi.org/10.1016/j.dendro.2014.01.002

Bakker JD (2005) A new, proportional method for reconstructing historical tree diameters. Can J For Res 35(10):2515-2520. https://doi.org/10.1139/X05-136

Bekryaev RV, Polyakov IV, Alexeev VA (2010) Role of polar amplification in longterm surface air temperature variations and modern Arctic warming. J Clim 23:3888-3906. https://doi.org/10.1175/2010JCLI3297.1

Biondi F, Waikul K (2004) DENDROCLIM2002: a C++ program for statistical calibration of climate signals in tree-ring chronologies. Comput Geosci 30: 303-311. https://doi.org/10.1016/j.cageo.2003.11.004

Briffa KR, Melvin TM, Osborn TJ, Hantemirov RM, Kirdyanov AV, Mazepa VS, Shiyatov SG, Esper J (2013) Reassessing the evidence for tree-growth and inferred temperature change during the common era in Yamalia, Northwest Siberia. Quat Sci Rev 72:83-107. https://doi.org/10.1016/j. quascirev.2013.04.008

Briffa KR, Schweingruber FH, Jones PD, Osborn TJ, Shiyatov SG, Vaganov EA (1998) Reduced sensitivity of recent tree-growth to temperature at high northern latitudes. Nature 391:678-682. https://doi.org/10.1038/35596

Bunn AG, Goetz SJ, Kimball JS, Zhang K (2007) Northern high-latitude ecosystems respond to climate change. EOS Trans Am Geophys Union 88:333-335. https://doi.org/10.1029/2007EO340001

Canadell JG, Pataki DE, Gifford R, Houghton RA, Luo Y, Raupach MR, Smith P, Steffen W (2007) Saturation of the terrestrial carbon sink. In: Terrestrial ecosystems in a changing world. Springer, Berlin, Heidelberg, pp 59-78

Clark DA, Brown S, Kicklighter DW, Chambers JQ, Thomlinson JR, Ni J (2001) Measuring net primary production in forests: concepts and field methods Ecol Appl 11:356-370. https://doi.org/10.1890/1051-0761(2001)011[0356: MNPPIF]2.0.CO;2
Cook ER, Kairiukstis LA (1990) Methods of dendrochronology. Springer Netherlands, Dordrecht

Cook ER, Krusic PJ (2006) Program ARSTAN: a tree-ring standardization program based on detrending and autoregressive time series modeling, with interactive graphics. Tree-Ring Laboratory, Lamont Doherty Earth Observatory of Columbia University Palisades, New York

Cook ER, Peters K (1981) The smoothing spline: a new approach to standardizing forest interior tree-ring width series for dendroclimatic studies. Tree-Ring Bull 41:45-53

Core Writing Team RKP and LAM (2014) Climate change 2014: synthesis report. Contribution of working groups I. II and III to the fifth assessment report of the intergovernmental panel on climate change (IPCC), Geneva

Davis EL, Gedalof Z (2018) Limited prospects for future alpine treeline advance in the Canadian Rocky Mountains. Glob Chang Biol 24:4489-4504. https://doi. org/10.1111/gcb.14338

de Wit HA, Bryn A, Hofgaard A, Karstensen J, Kvalevåg MM, Peters GP (2014) Climate warming feedback from mountain birch forest expansion: reduced albedo dominates carbon uptake. Glob Chang Biol 20:2344-2355. https://doi. org/10.1111/gcb.12483

Devi N, Hagedorn F, Moiseev P, Bugmann H, Shiyatov S, Mazepa V, Rigling A (2008) Expanding forests and changing growth forms of Siberian larch at the Polar Urals treeline during the 20th century. Glob Chang Biol 14:1581-1591. https://doi.org/10.1111/j.1365-2486.2008.01583.x

Dye A, Plotkin AB, Bishop D, Pederson N, Poulter B, Hessl A (2016) Comparing tree-ring and permanent plot estimates of aboveground net primary production in three eastern U.S. forests. Ecosphere 7:e01454. https://doi.org/ 10.1002/ecs2.1454

Epstein HE, Beringer J, Gould WA, Lloyd AH, Thompson CD, Chapin FS III, Michaelson GJ, Ping CL, Rupp TS, Walker DA (2004) The nature of spatial transitions in the Arctic. J Biogeogr 31:1917-1933. https://doi.org/10.1111/j. 1365-2699.2004.01140.x

Esper J, Cook ER, Schweingruber FH (2002) Low-frequency signals in long treering chronologies for reconstructing past temperature variability. Science 295:2250-2253. https://doi.org/10.1126/science.1066208

Foley JA, Kutzbach JE, Coe MT, Levis S (1994) Feedbacks between climate and boreal forests during the Holocene epoch. Nature 371:52-54. https://doi.org/ 10.1038/371052a0

Frei ER, Bianchi E, Bernareggi G, Bebi P, Dawes MA, Brown CD, Trant AJ, Mamet SD, Rixen C (2018) Biotic and abiotic drivers of tree seedling recruitment across an alpine treeline ecotone. Sci Rep 8:10894. https://doi.org/10.1038/ s41598-018-28808-w

Fritts HC (1976) Tree rings and climate. Academic Press, London

Gamache I, Payette S (2005) Latitudinal response of subarctic tree lines to recent climate change in eastern Canada. J Biogeogr 32:849-862. https://doi.org/10. $1111 / j .1365-2699.2004 .01182 . x$

Gehrig-Fasel J, Guisan A, Zimmermann NE (2008) Evaluating thermal treeline indicators based on air and soil temperature using an air-to-soil temperature transfer model. Ecol Model 213:345-355. https://doi.org/10. 1016/j.ecolmodel.2008.01.003

Gonzalez P, Neilson RP, Lenihan JM, Drapek RJ (2010) Global patterns in the vulnerability of ecosystems to vegetation shifts due to climate change. Glob Ecol Biogeogr 19:755-768. https://doi.org/10.1111/j.1466-8238.2010.00558.x

Gorchakovsky P, Shiyatov S (1978) The upper forest limit in the mountains of the boreal zone of the USSR (in Russian). Arct Alp Res 10(2):349-363

Gower ST, McMurtrie RE, Murty D (1996) Aboveground net primary production decline with stand age: potential causes. Trends Ecol Evol 11:378-382

Grace J, Berninger F, Nagy L (2002) Impacts of climate change on the tree line. Ann Bot 90:537-544. https://doi.org/10.1093/AOB/MCF222

Grafius DR, Malanson GP (2015) Biomass distributions in dwarf tree, krummholz and tundra vegetation in the alpine treeline ecotone. Phys Geogr 36:337352. https://doi.org/10.1080/02723646.2015.1050954

Graumlich L, Brubaker LB, Grier CC (1989) Long-term trends in forest net primary productivity: Cascade Mountains, Washington. Ecology 70:405-410. https:// doi.org/10.2307/1937545

Grigorieva AV, Moiseev PA (2018) Peculiarities and determinants of regeneration of Siberian larch on the upper limit of its growth in the Urals. Contemp Prob Ecol 11:13-25. https://doi.org/10.1134/S1995425518010031

Hagedorn F, Shiyatov SG, Mazepa VS, Devi NM, Grigor'ev AA, Bartysh AA, Fomin W, Kapralov DS, Terent'ev M, Bugman H, Rigling A, Moiseev PA (2014) Treeline advances along the Urals mountain range - driven by improved winter conditions? Glob Chang Biol 20:3530-3543. https://doi. org/10.1111/gcb.12613 
Harsch MA, Hulme PE, McGlone MS, Duncan RP (2009) Are treelines advancing? A global meta-analysis of treeline response to climate warming. Ecol Lett 12: 1040-1049. https://doi.org/10.1111/j.1461-0248.2009.01355.x

Hoch G, Körner C (2009) Growth and carbon relations of tree line forming conifers at constant vs. variable low temperatures. J Ecol 97:57-66. https:// doi.org/10.1111/j.1365-2745.2008.01447.x

Holmes RL (1995) Dendrochronological program library (computer program). Laboratory of tree ring research. The University of Arizona, Tucson

Holtmeier F-K (2003) Mountain Timberlines. Ecology, Patchiness, and Dynamics. Kluwer, Dordrecht.

Holtmeier F-K (2009) Mountain timberlines. Springer Netherlands, Dordrech

Holtmeier F-K, Broll G (2007) Treeline advance - driving processes and adverse factors. Landsc Online:1-32. https://doi.org/10.3097/L0.200701

Houghton RA (2005) Aboveground forest biomass and the global carbon balance. Glob Chang Biol 11:945-958. https://doi.org/10.1111/j.1365-2486.2005.00955.x

Kammer A, Hagedorn F, Shevchenko I, Leifeld J, Guggenberger G, Goryacheva T, Rigling A, Moiseev P (2009) Treeline shifts in the Ural mountains affect soil organic matter dynamics. Global Change Biology 15(6): 1570-1583. https:// doi.org/10.1111/j.1365-2486.2009.01856.x

Keane RE, Mahalovich MF, Bollenbacher BL, Manning ME, Loehman RA, Jain TB, Holsinger LM, Larson AJ (2018) Effects of climate change on forest vegetation in the northern Rockies. In: Halofsky J, Peterson D (eds) Climate change and Rocky Mountain ecosystems, Advances in global change research, vol 63. Springer, Cham, pp 59-95. https://doi.org/10.1007/978-3319-56928-4 5

Kearney MS (1982) Recent seedling establishment at timberline in Jasper National Park, Alta. Can J Bot 60:2283-2287. https://doi.org/10.1139/b82-279

Kharuk VI, Im ST, Dvinskaya ML, Ranson KJ (2010) Climate-induced mountain treeline evolution in southern Siberia. Scand J Forest Res 25:446-454. https://doi. org/10.1080/02827581.2010.509329

Kharuk VI, Im ST, Dvinskaya ML, Ranson KJ, Petrov IA (2017) Tree wave migration across an elevation gradient in the Altai Mountains, Siberia. J Mt Sci 14:442452. https://doi.org/10.1007/s11629-016-4286-7

Kirdyanov AV, Hagedorn F, Knorre AA, Fedotova EV, Vaganov EA, Naurzbaev MM, Moiseev PA, Rigling A (2012) 20th century tree-line advance and vegetation changes along an altitudinal transect in the Putorana Mountains, northern Siberia. Boreas 41:56-67. https://doi.org/10.1111/j.1502-3885.2011.00214.x

Körner C (2012) Alpine treelines. Springer Basel, Basel

Körner C, Paulsen J (2004) A world-wide study of high altitude treeline temperatures. J Biogeogr 31:713-732. https://doi.org/10.1111/j.1365-2699.2003.01043.x

Kukarskih W, Devi NM, Moiseev PA, Grigoriev AA, Bubnov MO (2018) Latitudinal and temporal shifts in the radial growth-climate response of Siberian larch in the Polar Urals. J Mt Sci. https://doi.org/10.1007/s11629-017-4755-7

Kullman L, Engelmark O (1997) Neoglacial climate control of subarctic Picea abies stand dynamics and range limit in northern Sweden. Arct Alp Res 29:315. https://doi.org/10.2307/1552146

Kullman L, Öberg L (2009) Post-little ice age tree line rise and climate warming in the Swedish Scandes: a landscape ecological perspective. J Ecol 97:415-429. https://doi.org/10.1111/j.1365-2745.2009.01488.x

Lavoie C, Payette S (1992) Black spruce growth forms as a record of a changing winter environment at treeline, Quebec, Canada. Arct Alp Res 24:40. https:// doi.org/10.2307/1551318

Liu X, Nie Y, Kong G, Luo T (2016) Contrasting changes in above- and belowground biomass allocation across treeline ecotones in Southeast Tibet. J Mt Sci 13:2036-2045. https://doi.org/10.1007/s11629-016-4003-6

Lloyd AH (2005) Ecological histories from Alaskan tree lines provide insight into future change. Ecology 86:1687-1695. https://doi.org/10.1890/03-0786

Lloyd AH, Graumlich LJ (1997) Holocene dynamics of treeline forests in the Sierra Nevada. Ecology 78:1199. https://doi.org/10.2307/2265869

Loranty MM, Berner LT, Goetz SJ, Jin Y, Randerson JT (2014) Vegetation controls on northern high latitude snow-albedo feedback: observations and CMIP5 model simulations. Glob Chang Biol 20:594-606. https://doi.org/10.1111/gcb.12391

MacDonald GM, Kremenetski KV, Beilman DW (2008) Climate change and the northern Russian treeline zone. Philos Trans R Soc Lond Ser B Biol Sci 363: 2285-2299. https://doi.org/10.1098/rstb.2007.2200

Macias-Fauria M, Johnson EA (2013) Warming-induced upslope advance of subalpine forest is severely limited by geomorphic processes. PNAS 110: 8117-8122. https://doi.org/10.1073/pnas.1221278110

Matskovsky V (2016) Climatic signal in tree-ring width chronologies of conifers in European Russia. Int J Climatol 36:3398-3406. https://doi.org/ $10.1002 /$ joc.4563
Mazepa VS (2005) Stand density in the last millennium at the upper tree-line ecotone in the polar Ural Mountains. Can J For Res 35:2082-2091. https://doi. org/10.1139/x05-111

Moiseev PA (2002) Effect of climatic changes on radial increment and age structure formation in high-mountain larch forests of the Kuznetsk Ala tau. Russ J Ecol 33:7-13. https://doi.org/10.1023/A:1013659319452

Moiseev PA, Bubnov MO, Devi NM, Nagimov ZY (2016) Changes in the structure and phytomass of tree stands at the upper limit of their growth in the Southern Urals. Russ J Ecol 47:219-227. https://doi.org/10.1134/ S1067413616030085

Myneni RB, Keeling CD, Tucker CJ, Asrar G, Nemani RR (1997) Increased plant growth in the northern high latitudes from 1981 to 1991. Nature 386:698702. https://doi.org/10.1038/386698a0

Nicolussi K, Bortenschlager S, Körner C (1995) Increase in tree-ring width in subalpine Pinus cembra from the Central Alps that may be $\mathrm{CO}_{2}$-related. Trees 9:181-189. https://doi.org/10.1007/BF00195270

Niklasson M (2002) A comparison of three age determination methods for suppressed Norway spruce: implications for age structure analysis. Forest Ecol Manag 161:279-288. https://doi.org/10.1016/S0378-1127(01)00500-X

Pan Y, Birdsey RA, Phillips OL, Jackson RB (2013) The structure, distribution, and biomass of the world's forests. Annu Rev Ecol Evol S 44:593-622. https://doi. org/10.1146/annurev-ecolsys-110512-135914

Paulsen J, Körner C (2014) A climate-based model to predict potential treeline position around the globe. Alp Bot 124:1-12. https://doi.org/10. 1007/s00035-014-0124-0

Renard SM, Mclntire EJB, Fajardo A (2016) Winter conditions - not summer temperature - influence establishment of seedlings at white spruce alpine treeline in eastern Quebec. J Veg Sci 27:29-39. https://doi.org/10.1111/jvs.12347

Rinn F (1996) Tsap V 3.6 reference manual: computer program for tree-ring analysis and presentation. Bierhelder weg 20, D-69126, Heidelberg

Rossi S, Deslauriers A, Anfodillo T, Carraro V (2007) Evidence of threshold temperatures for xylogenesis in conifers at high altitudes. Oecologia 152:112. https://doi.org/10.1007/s00442-006-0625-7

Rossi S, Deslauriers A, Griçar J, Seo J-W, Rathgeber CBK, Anfodillo T, Morin H, Levanic T, Oven P, Jalkanen R (2008) Critical temperatures for xylogenesis in conifers of cold climates. Glob Ecol Biogeogr 17:696-707. https://doi.org/10. $1111 / j .1466-8238.2008 .00417 . x$

Schwaab J, Bavay M, Davin E, Hagedorn F, Hüsler F, Lehning M, Schneebeli M, Thürig E, Bebi P (2015) Carbon storage versus albedo change: radiative forcing of forest expansion in temperate mountainous regions of Switzerland. Biogeosciences 12:467-487. https://doi.org/10.5194/bg-12-467-2015

Shiyatov SG (1967) Climate fluctuations and age structure of tree stands in open larch forests of the Polar Ural Mountains, in tundra vegetation and the ways of its utilization. Nauka, Leningrad, pp 271-278 (in Russian)

Shiyatov SG (1986) Dendrochronology of the upper forest boundary in the Urals. Nauka, Moscow (in Russian)

Shiyatov SG, Mazepa VS (2015) Contemporary expansion of Siberian larch into the mountain tundra of the Polar Urals. Russ J Ecol 46:495-502. https://doi. org/10.1134/S1067413615060168

Shiyatov SG, Terent'ev MM, Fomin W (2005) Spatiotemporal dynamics of foresttundra communities in the Polar Urals. Russ J Ecol 36:69-75. https://doi.org/ 10.1007/s11184-005-0051-9

Shiyatov SG, Terent'ev MM, Fomin W, Zimmermann NE (2007) Altitudinal and horizontal shifts of the upper boundaries of open and closed forests in the Polar Urals in the 20th century. Russ J Ecol 38:223-227. https://doi.org/10. 1134/S1067413607040017

Speed JDM, Martinsen V, Hester AJ, Holand $\varnothing$, Mulder J, Mysterud A, Austrheim G (2015) Continuous and discontinuous variation in ecosystem carbon stocks with elevation across a treeline ecotone. Biogeosciences 12:1615-1627. https://doi.org/10.5194/bg-12-1615-2015

Suarez F, Binkley D, Kaye MW, Stottlemyer R (1999) Expansion of forest stands into tundra in the Noatak National Preserve, Northwest Alaska. Écoscience 6: 465-470. https://doi.org/10.1080/11956860.1999.11682538

Taylor AH (1995) Forest expansion and climate change in the mountain hemlock (Tsuga mertensiana) zone, Lassen volcanic National Park, California, U.S.a. Arct Alp Res 27:207-216. https://doi.org/10.2307/1551951

Vaganov EA, Shiyatov SG, Mazepa VS (1996) Dendroclimatic investigation in UralSiberian subarctic. Nauka, Novosibirsk (in Russian)

Walther G-R, Post E, Convey P, Menzel A, Parmesan C, Beebee TJC, Fromentin JM, Hoegh-Guldberg O, Bairlein F (2002) Ecological responses to recent climate change. Nature 416:389-395. https://doi.org/10.1038/416389a 
Wardle P, Coleman MC (1992) Evidence for rising upper limits of four native New Zealand forest trees. New Zeal J Bot 30:303-314. https://doi.org/10.1080/ 0028825X.1992.10412909

Weisberg PJ, Baker WL (1995) Spatial variation in tree regeneration in the foresttundra ecotone, Rocky Mountain National Park, Colorado. Can J For Res 25: 1326-1339. https://doi.org/10.1139/x95-145

Woodward Fl, Lomas MR, Kelly CK (2004) Global climate and the distribution of plant biomes. Philos T Roy Soc B 359:1465-1476. https://doi.org/10.1098/rstb. 2004.1525

Xu K, Wang X, Liang P, Wu Y, An H, Sun H, Wu P, Wu X, Li Q, Guo X, Wen X, Han W, Liu C, Fan D (2019) A new tree-ring sampling method to estimate forest productivity and its temporal variation accurately in natural forests. Forest Ecol Manag 433:217-227. https://doi.org/10.1016/J.FORECO.2018.10.066

Yatskov M, Harmon ME, Krankina ON (2003) A chronosequence of wood decomposition in the boreal forests of Russia. Can J For Res 33:1211-1226. https://doi.org/10.1139/x03-033

Zolkos SG, Goetz SJ, Dubayah R (2013) A meta-analysis of terrestrial aboveground biomass estimation using lidar remote sensing. Remote Sens Environ 128: 289-298. https://doi.org/10.1016/J.RSE.2012.10.017

\section{Submit your manuscript to a SpringerOpen ${ }^{\circ}$ journal and benefit from:}

- Convenient online submission

- Rigorous peer review

- Open access: articles freely available online

- High visibility within the field

- Retaining the copyright to your article

Submit your next manuscript at $\boldsymbol{\nabla}$ springeropen.com 